\title{
Genetic confirmation of the species status of Jabouilleia naungmungensis
}

\author{
Swen C. Renner ${ }^{1,2}$ (1) J John H. Rappole ${ }^{2}$ Myint Kyaw $^{3} \cdot$ Chris M. Milensky $^{4}$. \\ Martin Päckert ${ }^{5}$
}

Received: 31 May 2017/Revised: 9 August 2017/ Accepted: 22 August 2017 /Published online: 4 September 2017

(C) The Author(s) 2017. This article is an open access publication

\begin{abstract}
Species assessment of allopatric taxa is problematic. Here we consider the case of the Naung Mung Scimitar Babbler (Jabouilleia naungmungensis) from northern Myanmar. This bird was recognized as a new species in its original description, but was subsequently considered to be a subspecies of J. danjoui. We review the procedures used to make this assessment, and consider them in light of morphological (significantly different bill and hallux claw lengths) and new genetic (7.0\% genetic distance, cytochrome $b$ ) information. Based on this reconsideration, taking acoustic information into account, we conclude that the data unequivocally confirm the recognition of J. naungmungensis as a full species.
\end{abstract}

\section{Keywords Jabouilleia danjoui · Jabouilleia} naungmungensis $\cdot$ Rimator $\cdot$ Napothera $\cdot$ Species description · Taxonomy · Nomenclature · Timaliidae . Allopatric species

\section{Communicated by M. Wink.}

Swen C. Renner

swen.renner@boku.ac.at

1 Institute of Zoology, University of Natural Resources and Life Sciences, Gregor-Mendel-Straße 33, 1180 Vienna, Austria

2 Smithsonian Conservation Biology Institute, Smithsonian Institution, Front Royal, VA, USA

3 Hponkan Razi Headquarter, Putao, Kachin, Myanmar

4 National Museum of Natural History, Smithsonian Institution, Constitution Avenue, Washington, DC, USA

5 Senckenberg Natural History Collections, Museum of Zoology, Königsbrücker Landstraße 159, 01109 Dresden, Germany

\section{Zusammenfassung}

Jabouilleia naungmungensis ist eindeutig eine Art: Bestätigung durch genetische Analysen

Die Einstufung allopatrischer Taxa ist grundsätzlich problematisch. Hier betrachten wir den Fall des Naung Mung Krummschnabelsäblers (Jabouilleia naungmungensis) aus dem nördlichen Myanmar. J. naungmungensis wurde ursprünglichen als eine neue Vogelart beschrieben, basierend auf akustischen und morphologischen Unterschieden, aber nachfolgend lediglich als eine Unterart von $J$. danjoui anerkannt, letzteres ausschließlich basierend auf Unterschieden in der Gefiederfärbung. Wir analysieren hier alle bisherigen Ansätze, die zu diesen unterschiedlichen Bewertungen führten, und schließen alle zur Verfügung stehenden morphologischen (signifikante Unterschiede in Schnabel- und Klauenlänge) und neue genetische Informationen mit ein $(7,0 \%$ genetische Distanz, Cytochrom-b). Unter Berücksichtigung von bioakustischen Daten bleibt als einzige Schlussfolgerung, dass $J$. naungmungensis eine vollständige Art ist.

\section{Introduction}

Jabouilleia naungmungensis, the Naung Mung Scimitar Babbler, was described and recognized as a full species by Rappole et al. (2005) based mainly on acoustic and morphological differences from its closest known relative, $J$. danjoui, from Vietnam. Additional information on the behavior and general biology of the new species was provided by Rappole et al. (2008). However, in the account of $J$. danjoui provided by Collar and Robson (2007) in the 
Handbook of the Birds of the World, the taxon was relegated to subspecific status. This difference in taxonomic treatment was subsequently debated in the literature and in online forums (Alström et al. 2013; Collar 2011; Collar and Pilgrim 2007; Eames and Mahood 2011; Moyle et al. 2012; Nyári and Reddy 2013; Oliveros et al. 2012; Rappole et al. 2005, 2008; Reddy 2008; Reddy and Moyle 2011; Renner et al. 2015). At present, taxonomic authorities appear to be following the arguments presented by Collar (2011) in treating $J$. naungmungensis as a subspecies of $J$. danjoui (Dickinson and Christidis 2014) or Napothera danjoui (Clements et al. 2015) (for differences between the two generic classifications, refer to Fig. 1).

The data upon which Collar and colleagues first based their conclusion regarding the status of $J$. naungmungensis rests principally on a subjective comparison of color differences and a limited morphometric analysis (Collar 2011; Collar and Pilgrim 2007). Meanwhile, del Hoyo and Collar (2016) revised the subspecific treatment of naungmungensis by ranking "the form provisionally to species rank" under specific preconditions on the available acoustic information.

Here we present a new analysis of the species status of the two taxa, taking into consideration all available acoustic, ecological, and morphological data, and including

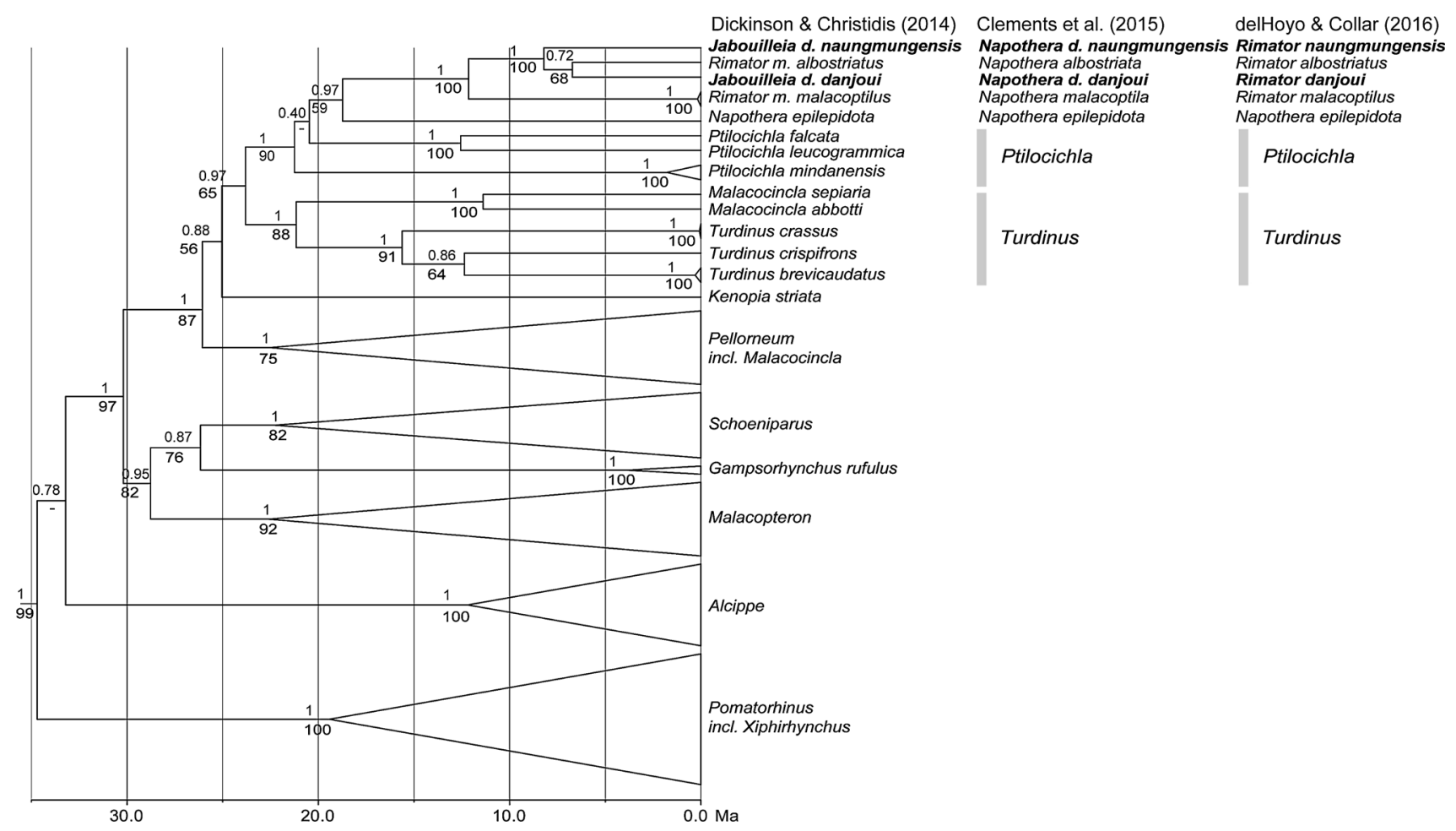

Fig. 1 Phylogenetic relationships of Jabouilleia naungmungensis; multilocus phylogeny based on two mitochondrial genes (cytochrome $b$ : $1134 \mathrm{bp}$, ND2: $1041 \mathrm{bp}$ ) and one nuclear intron (TGFB2: $610 \mathrm{bp}$ ); support from Bayesian posterior probabilities and RAxML bootstrap new molecular genetic information, which unambiguously indicate that $J$. naungmungensis should have species status.

\section{Methods and materials}

In addition to published information on plumage color, morphological traits, ecology, and acoustics (all cited where appropriate), we add new morphometric and molecular genetic data obtained via procedures described below.

\section{Target taxa}

The genus Jabouilleia consists of two species, Jabouilleia danjoui and J. naungmungensis, each with a limited range (Fig. 2). Records for $J$. danjoui derive from two mountainous areas of Vietnam, extending into Laos (Fig. 2). Specimen records for $J$. naungmungensis come only from far-northern Myanmar, although there are sight records from the border region between China (Yunnan state) and Myanmar (Kachin) about $300 \mathrm{~km}$ south of the original encounter site (Renner et al. 2015).

The Short-tailed Scimitar Babbler, sometimes also called the Indochinese Wren Babbler (particularly when it is placed in the genus Rimator), was first described by 


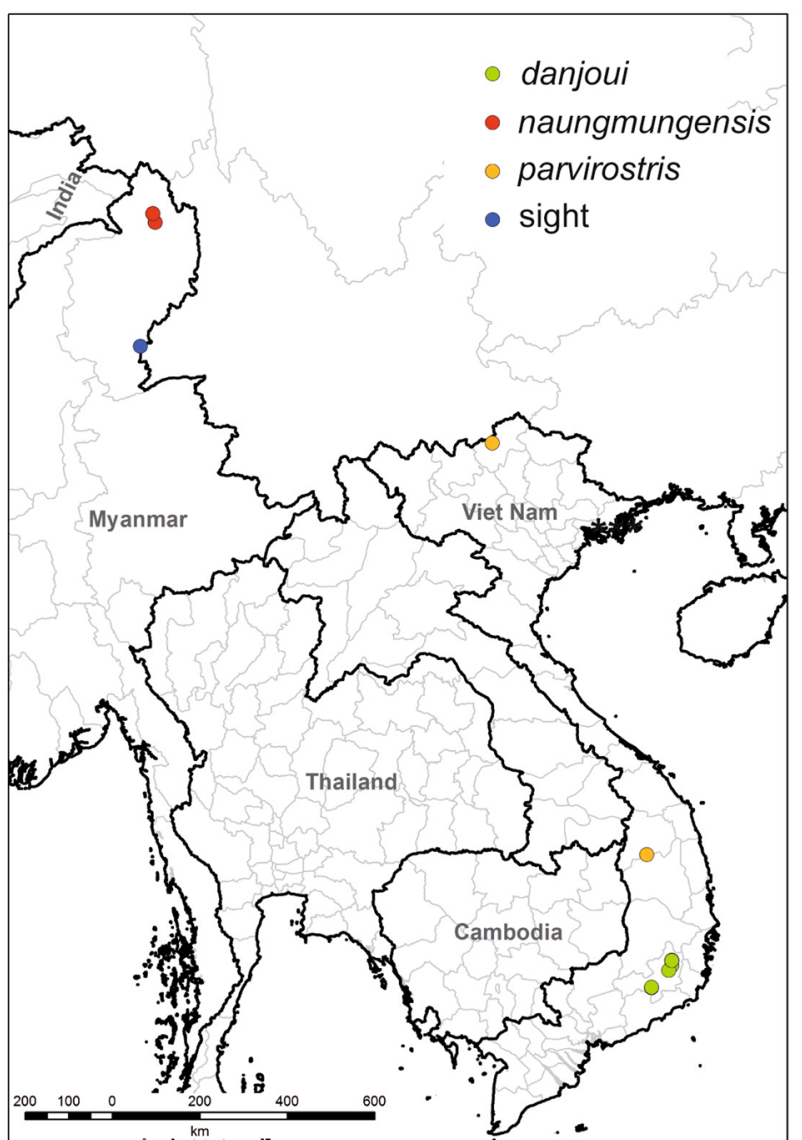

Fig. 2 Left distribution map of the Jabouilleia specimens analyzed. Right differences in six morphological parameters (boxplots) between Jabouilleia naungmungensis (red) and J. danjoui (green; including

Robinson and Kloss (1919) as Jabouilleia danjoui from Lang Bian Peaks, Vietnam $\left(12^{\circ} 02^{\prime} \mathrm{N}, 108^{\circ} 26^{\prime} \mathrm{E}\right)$. According to Collar and Robson (2007), five subspecies are known but most are not yet considered to be valid. $J$. d. parvirostris, originally described by Delacour (1927), is the taxon known from north-central Vietnam and Central Laos (Dickinson and Christidis 2014). J. d. parvirostris shows a slightly darker breast band than danjoui does; parvirostris otherwise resembles danjoui in plumage.

\section{Molecular genetics}

To perform comparisons with available sequences of Jabouilleia danjoui and related babblers (data set for comparison from Moyle et al. 2012), we extracted DNA from one tissue sample of a J. naungmungensis specimen (sample number 3318, specimen currently at BOKU; Table 1), which was also included in all morphological analyses.

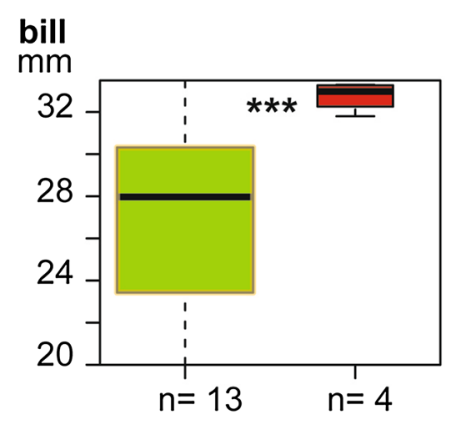

hallux

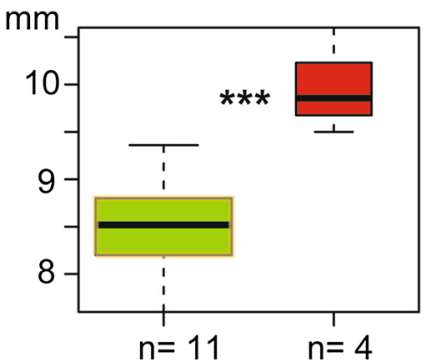

wing

$\mathrm{mm}$

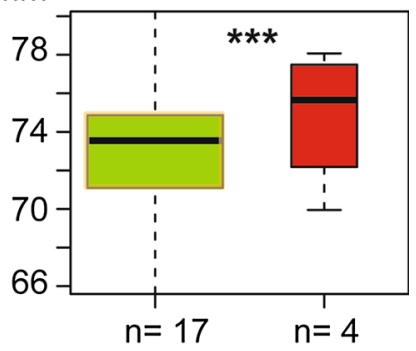

tarsus

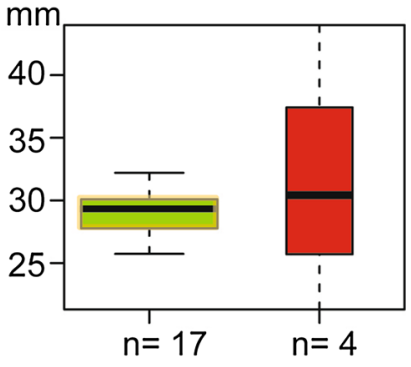

tail furcation

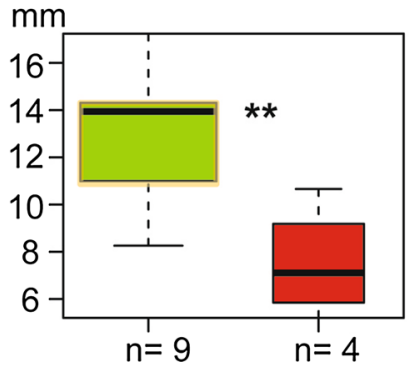

tail (inner)

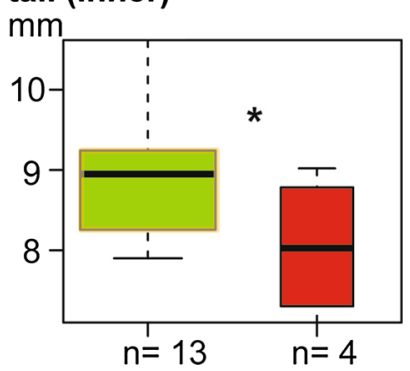

subspecies danjoui and parvirostris, because the latter two are not distinguishable by morphometrics); significance levels: $* p<0.05$, $* * p<0.005, * * * p<0.001$; ANOVA (color figure online)

We amplified two mitochondrial genes: cytochrome $b$ (cyt $b$ ), NADH dehydrogenase subunit 2 (ND2), and one nuclear marker: the fifth intron of the transforming growth factor $\beta 2$ (TGFB2). For details on DNA extraction, primer combinations, and PCR and sequencing protocols, see Päckert et al. (2010). New sequences were deposited at GenBank under accession numbers MF563986 (COI), MF563987 (cytb), MF563988 (ND2), and MF563989 (TGFB2). To perform phylogenetic reconstruction, we included our sequence data in the core babbler data set of Moyle et al. (2012), available at TreeBASE (ID = MD 12,899). We furthermore included sequences of another close relative of Jabouilleia, the Sumatran Wren Babbler, Rimator albostriatus (from Reddy and Moyle 2011). Sequences were aligned with MEGA v6 (Tamura et al. 2013) and manually corrected after visual inspection.

We reconstructed a multi-locus phylogeny based on three markers (cytb, ND2, and TGFB2) with BEAST 


\begin{tabular}{|c|c|c|c|c|c|c|c|c|c|c|c|c|}
\hline 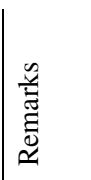 & 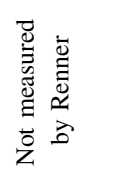 & 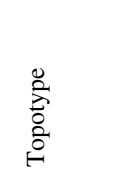 & 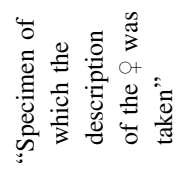 & $\stackrel{\pi}{\nexists}$ & 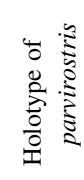 & $\frac{3}{2}$ & $\stackrel{\pi}{\Xi}$ & 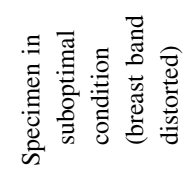 & 赵 & 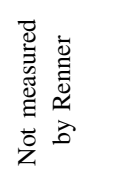 & 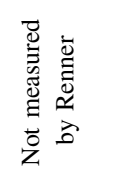 & 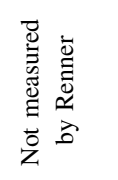 \\
\hline 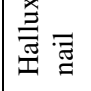 & $\stackrel{\Xi}{\cong}$ & ळ్ & $\begin{array}{c}\text { तิ } \\
\infty\end{array}$ & $\underset{\sim}{\stackrel{8}{r}}$ & $\stackrel{\substack{\infty \\
\infty}}{2}$ & న్ & $\begin{array}{l}0 \\
\infty \\
\infty\end{array}$ & 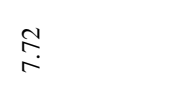 & $\underset{\infty}{+\infty}$ & $\Xi$ & $\stackrel{\Xi}{\Xi}$ & $\stackrel{\pi}{\Xi}$ \\
\hline 苞 & $\cong$ & $\Xi$ & ठे & $\Xi$ & $\Xi$ & $\begin{array}{l}\bar{\partial} \\
\dot{I}\end{array}$ & $\underset{\infty}{\stackrel{2}{\infty}}$ & $\stackrel{\text { I্ }}{\Xi}$ & $\begin{array}{l}\vec{m} \\
\stackrel{J}{J}\end{array}$ & $\stackrel{\tilde{g}}{g}$ & $\stackrel{\Xi}{g}$ & $\stackrel{\Xi}{\rightleftarrows}$ \\
\hline 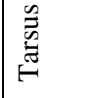 & 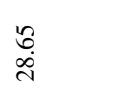 & $\underset{\text { స్ }}{\text { స్ }}$ & $\begin{array}{l}\text { में } \\
\text { ते }\end{array}$ & 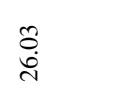 & $\stackrel{\substack{c \\
\dot{i}}}{2}$ & $\begin{array}{l}\bar{\alpha} \\
\text { वे }\end{array}$ & $\begin{array}{l}\infty \\
\stackrel{\infty}{0} \\
\stackrel{d}{0}\end{array}$ & $\begin{array}{l}\stackrel{0}{0} \\
\stackrel{\text { D }}{ }\end{array}$ & 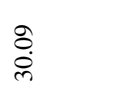 & $\frac{n}{2}$ & $\overrightarrow{\vec{m}}$ & $\frac{\bar{m}}{m}$ \\
\hline$\stackrel{\ominus}{\oplus}$ & $\Xi$ & $\begin{array}{l}\infty \\
\text { m. } \\
\infty \\
i n\end{array}$ & $\begin{array}{l}\tilde{\text { In }} \\
\text { in }\end{array}$ & 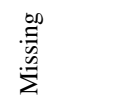 & $\begin{array}{l}\overline{\bar{\sigma}} \\
\bar{\Sigma}\end{array}$ & $\begin{array}{l}\infty \\
\stackrel{\infty}{+} \\
\dot{+}\end{array}$ & $\begin{array}{l}\tilde{\Im} \\
\stackrel{g}{q}\end{array}$ & $\begin{array}{l}\stackrel{q}{q} \\
\stackrel{q}{q}\end{array}$ & $\begin{array}{l}\vec{F} \\
\dot{y}\end{array}$ & $\Xi$ & $\stackrel{\pi}{\Xi}$ & $\Xi$ \\
\hline$\dot{F}$ & $\begin{array}{l}8 \\
\stackrel{8}{+} \\
i\end{array}$ & $\stackrel{\Xi}{\nexists}$ & $\overrightarrow{\vec{T}}$ & 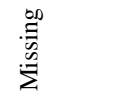 & $\begin{array}{l}8 \\
\dot{0} \\
\dot{i n}\end{array}$ & $\begin{array}{l}\dot{g} \\
\dot{d} \\
\dot{0}\end{array}$ & $\begin{array}{l}\stackrel{\infty}{\infty} \\
\infty \\
\infty\end{array}$ & $\begin{array}{l}\stackrel{8}{0} \\
\dot{+}\end{array}$ & $\stackrel{\text { in }}{\text { in }}$ & 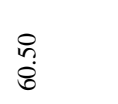 & $\begin{array}{l}8 \\
\dot{0} \\
\end{array}$ & $\begin{array}{l}0 \\
\text { 号 } \\
0\end{array}$ \\
\hline 3 & $\stackrel{\stackrel{n}{n}}{\stackrel{2}{r}}$ & $\begin{array}{l}\infty \\
\stackrel{\infty}{i} \\
\stackrel{1}{i}\end{array}$ & $\begin{array}{l}\stackrel{\partial}{\alpha} \\
\stackrel{p}{r}\end{array}$ & $\begin{array}{l}\stackrel{n}{m} \\
\stackrel{n}{n}\end{array}$ & $\begin{array}{l}\hat{n} \\
\text { मे }\end{array}$ & $\begin{array}{l}\text { ते } \\
\stackrel{\infty}{\infty}\end{array}$ & 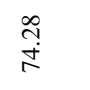 & $\stackrel{\hat{a}}{\stackrel{2}{r}}$ & $\begin{array}{l}\text { مू } \\
\text { s. }\end{array}$ & $\stackrel{\stackrel{i n}{i n}}{\stackrel{i}{i}}$ & $\begin{array}{l}8 \\
8 \\
i\end{array}$ & $\begin{array}{l}8 \\
80 \\
8\end{array}$ \\
\hline 蛋 & $\Xi$ & $\begin{array}{l}n \\
n \\
n\end{array}$ & $\stackrel{\sigma}{\sigma}$ & 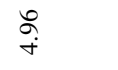 & $\underset{\leftarrow}{\tilde{r}}$ & तે & $\cong$ & $\frac{n}{n}$ & $\begin{array}{l}\infty \\
\infty \\
\stackrel{+}{+}\end{array}$ & $\cong$ & $\Xi$ & $\stackrel{\Xi}{\Xi}$ \\
\hline 客 & $\stackrel{\Xi}{a}$ & $\underset{+}{\stackrel{\leftrightarrow}{+}}$ & $\stackrel{\check{\alpha}}{\dot{r}}$ & $\stackrel{n}{n}$ & $\stackrel{\stackrel{m}{m}}{\stackrel{m}{*}}$ & 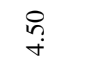 & 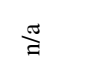 & $\stackrel{\text { ڤ̆ }}{\text { r. }}$ & $\underset{\stackrel{f}{i}}{\stackrel{f}{n}}$ & $\Xi$ & $\stackrel{\pi}{\Xi}$ & $\stackrel{\pi}{\Xi}$ \\
\hline$\vec{m}$ & $\stackrel{\pi}{\Xi}$ & 吕 & 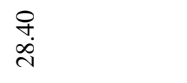 & $\stackrel{\infty}{\stackrel{m}{m}}$ & $\begin{array}{l}8 \\
\stackrel{\sim}{~}\end{array}$ & $\begin{array}{l}\bar{n} \\
\text { ते }\end{array}$ & 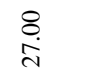 & 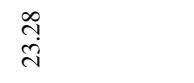 & $\stackrel{m}{m}$ & $\stackrel{\pi}{\Xi}$ & $\stackrel{\Xi}{\Xi}$ & $\stackrel{\pi}{\Xi}$ \\
\hline$\stackrel{\varpi}{\check{\varpi}}$ & ષ્ণ & ळે & $\stackrel{\infty}{2}$ & $\frac{\infty}{2}$ & ఏ్ర & $\hat{\sigma}$ & $\widehat{\sigma}$ & $\stackrel{\infty}{\circ}$ & $\stackrel{\partial}{\partial}$ & 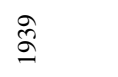 & ळે & ळે \\
\hline$\overline{\bar{\sigma}}$ & in & $=$ & $\nabla$ & + & $\infty$ & $n$ & $m$ & 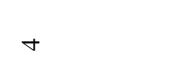 & 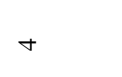 & $m$ & $m$ & $m$ \\
\hline$\vec{\Xi}$ & $=$ & $m$ & $\infty$ & तi & \pm & $=$ & $=$ & $\stackrel{i}{i}$ & $\hat{\lambda}$ & $r$ & $\simeq$ & $\simeq$ \\
\hline 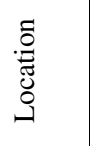 & 尊勇吉 & 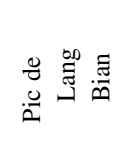 & 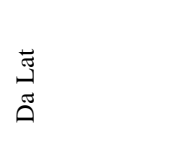 & 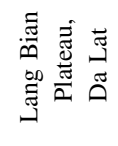 & 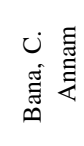 & 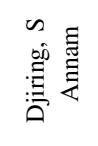 & 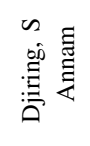 & 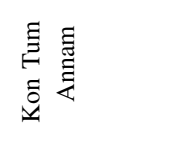 & 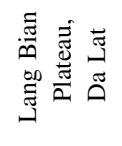 & 吅. 志 & 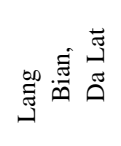 & 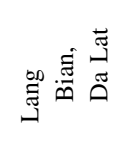 \\
\hline 离 & 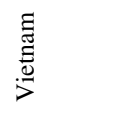 & 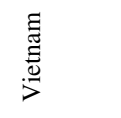 & 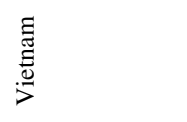 & 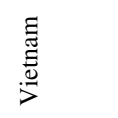 & 昙 & $\begin{array}{l}\text { E } \\
\stackrel{\Xi}{0} \\
5\end{array}$ & $\begin{array}{l}\text { E } \\
\stackrel{\Xi}{0} \\
\stackrel{0}{5}\end{array}$ & 胥 & 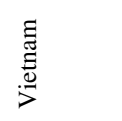 & $\begin{array}{l}\text { E్ } \\
\stackrel{\Xi}{0} \\
\stackrel{0}{\circ}\end{array}$ & 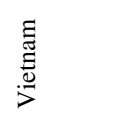 & 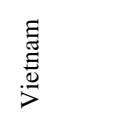 \\
\hline ڤ్ & I & $\stackrel{\pi}{\Xi}$ & $山$ & $\Sigma$ & $\Sigma$ & $\Sigma$ & $\tilde{\Sigma}$ & $\Sigma$ & $\Sigma$ & 山 & $\Sigma$ & $\stackrel{\pi}{\Xi}$ \\
\hline 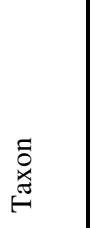 & 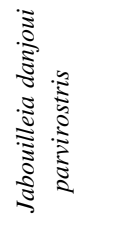 & 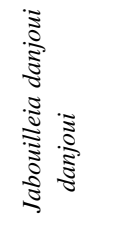 & 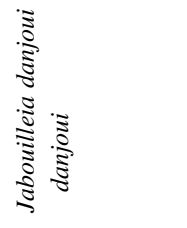 & 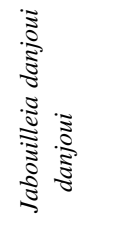 & 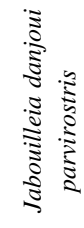 & 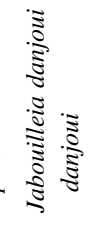 & 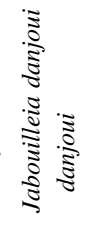 & 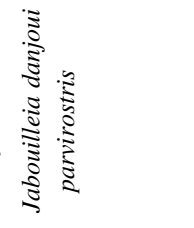 & 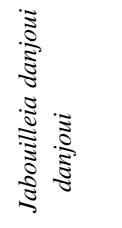 & 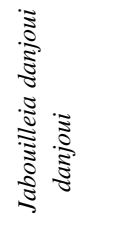 & 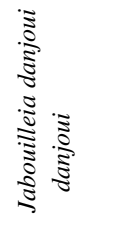 & 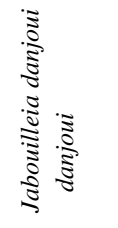 \\
\hline 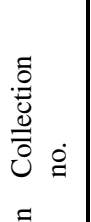 & $\begin{array}{l}4 \\
\vdots \\
\infty \\
\infty \\
\infty\end{array}$ & $\begin{array}{l}+ \\
\substack{+0 \\
\infty \\
\infty \\
\infty}\end{array}$ & 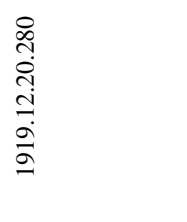 & 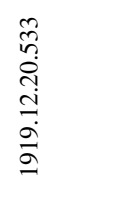 & 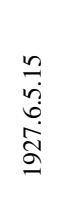 & 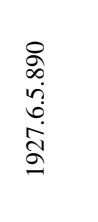 & 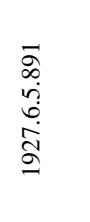 & $\begin{array}{l}\underset{+}{ \pm} \\
\underset{\infty}{\infty} \\
\stackrel{0}{a}\end{array}$ & 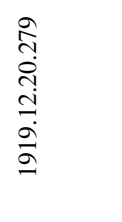 & 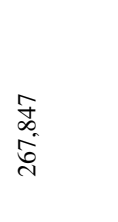 & 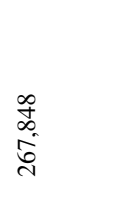 & 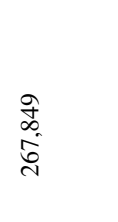 \\
\hline 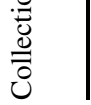 & 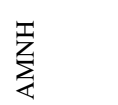 & 荾 & 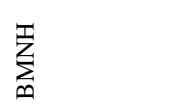 & $\sum_{m}^{\mathbb{J}}$ & $\sum_{m}^{\bar{Z}}$ & $\sum_{m}^{\bar{Z}}$ & $\sum_{m}^{\bar{T}}$ & $\sum_{m}^{\mathbb{Z}}$ & $\sum_{m}^{\mathbb{T}}$ & $\tilde{D}_{\Sigma}^{N}$ & $\stackrel{N}{N}$ & $\underset{\Sigma}{N}$ \\
\hline
\end{tabular}




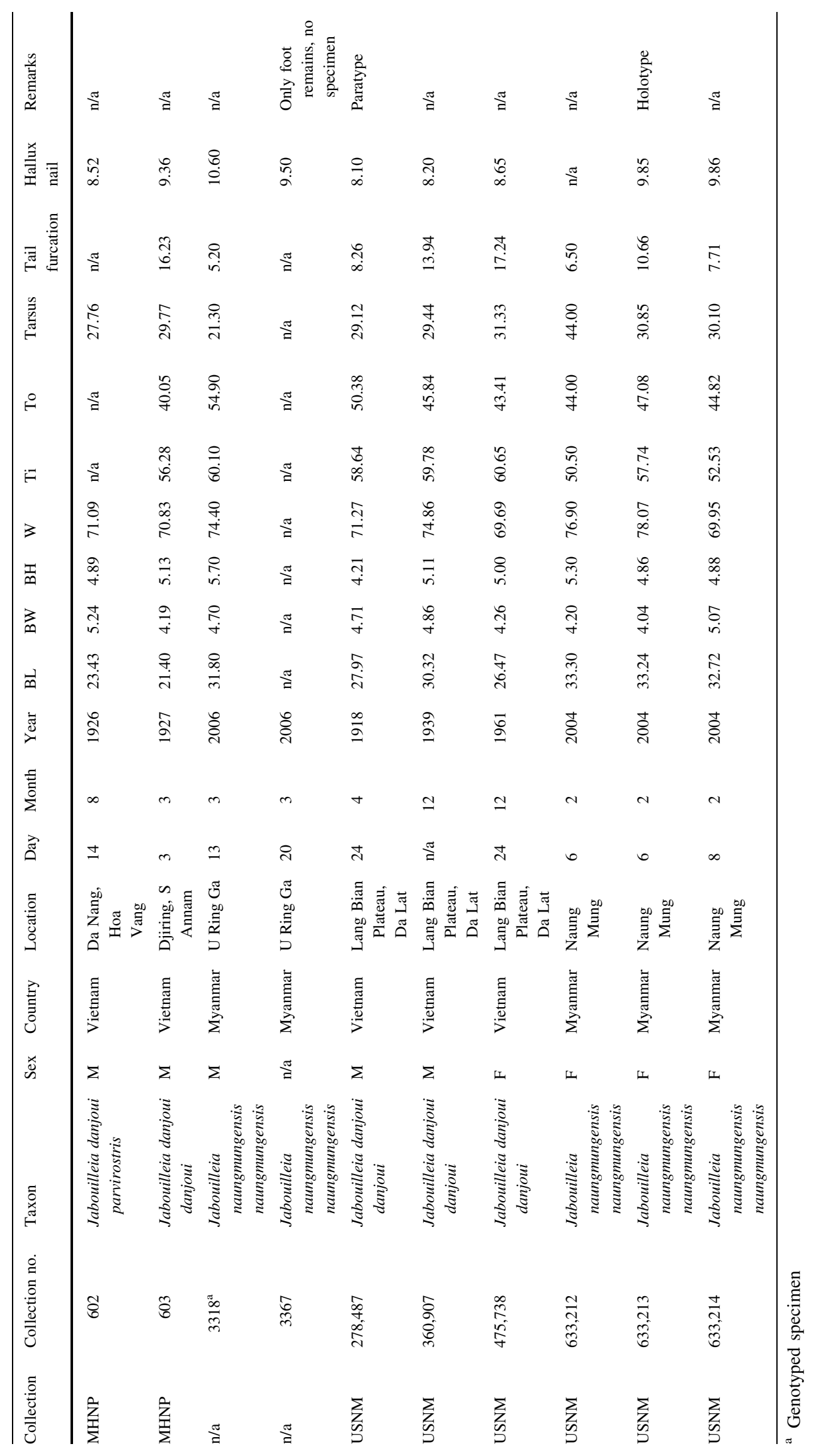


v.1.8.1 (Drummond and Rambaut 2007). We ran BEAST for $10,000,000$ generations (trees sampled every 1000 generations) under the uncorrelated lognormal clock model for all loci with the "auto-optimize" option activated and a Yule process prior (speciation) applied to the tree. A GTR $+\mathrm{I}+\Gamma$ model was applied to each partition of the one- and two-partition schemes and the two mitochondrial genes were further partitioned by codon position. In the absence of reliable passerine fossils providing appropriate node age constraints, we estimated divergence times between clades using an empirical substitution rate of 0.0105 substitutions per site/lineage/million years for cyt $b$, as evaluated by Weir and Schluter (2008). We applied this rate to the cyt $b$ partition, and left the rates of all other loci to be estimated relative to the cyt $b$ rate. The log files were examined with Tracer v.1.4.8 (Drummond and Rambaut 2007) in order to ensure effective sample sizes (ESS; which yielded reasonable values for all parameters after 10,000,000 generations). Trees were summarized with TreeAnnotator v.1.4.8 (posterior probability limit $=0.5$ ) using a burn-in value of 3000 (trees) and with the median height annotated to each node.

Node support in a ML framework was obtained by constructing 1000 bootstrap replicates with RAxML ("thorough" bootstrap option, 100 replicates) (Stamatakis 2006) using the Python-based GUI developed by Silvestro and Michalak (2012). The concatenated matrix was partitioned and the GTR $+\mathrm{I}+\Gamma$ model was applied across partitions.

\section{Morphometry}

We found a total of 22 specimens in the collections of the AMNH (1 specimen), ANSP (1), BMNH (8), MCZ (3), MHNP (2), BOKU (1), and USNM (6) (acronyms of the collections are defined in the "Acknowledgements"). These specimens are likely to be all of the available specimens of the genus Jabouilleia worldwide. Measurements were generally performed by Renner (exceptions are labeled as such in Table 1).

Besides noting species and subspecies, as indicated on the labels, we added information (when available) on country, exact location, elevation, the collectors, and collection date. We measured with a digital caliper to the nearest $0.1 \mathrm{~mm}$ for hard parts and $0.5 \mathrm{~mm}$ for feathers. In general, we followed the measuring guide of Eck et al. (2011). We measured bill length from the distal end of the operculum to the tip (which mostly resembles the exposed culmen) as well as bill width and bill height at the operculum. The wing was measured from the bend of the wing to the tip of the longest primary, unflattened on the bird's right side. The tarsus was measured from the distal to the proximal end of the tarsometatarsus on the bird's right side
(Svensson 1992). The outer and innermost rectrices were measured from insertion to the tip of the innermost/outermost rectrix on the bird's right side (all bilateral measures were preferably obtained on the right side; they were only measured on the left body side if they could not be measured on the right side or there was a defect on the right side). Tail furcation was calculated as the innermost minus the outermost rectrix. We measured the hallux claw on the ventral side of the claw from the skin to the tip.

We tested the variance in the morphometric measurements with an ANOVA for each parameter based on the statistical hypothesis that we had two groups (Myanmar vs. Vietnam/Laos). We tested whether each parameter was normally distributed with a Shapiro-Wilk test (except for the tarsus, all were normally distributed, $p>0.05)$ and subsequently applied a Kruskal-Wallis ANOVA to the tarsus.

\section{Results}

Unexpectedly, the two Jabouilleia taxa did not present as a monophyletic clade in the multilocus tree: J. danjoui was a sister to $R$. albostriatus, albeit with poor support, and $J$. naungmungensis was a sister to both of them (Fig. 1). This relationship must be treated with care, because it relies on the mitochondrial signal only (a TGFB2 sequence was not available for $R$. albostriatus). A sister-group relationship between the Jabouilleia/R. albostriatus clade and the Long-Billed Wren Babbler Rimator malacoptilus received strong support. The uncorrected $p$-distance value between $J$. danjoui and $R$. albostriatus was $5.1 \%$ (cyt $b$ sequence comparison), whereas the genetic divergence between $J$. naungmungensis and the latter two was greater (7.0-7.7\%). That distance is comparable to genetic divergences between sister species from the same clade, e.g., Ptilocichla leucogrammica/P. falcata (7.1\%) and Malacocincla sepiaria/M. abotti (9.4\%), and greatly exceeds genetic distances between sister species from other babbler clades, e.g., Alcippe grotei/A. poioicephala (4.0\%). The p-distance value between the two Jabouilleia species corresponded to a divergence time estimate of about 8 Mya, i.e., a Late Miocene lineage split.

Measurements were taken from 22 specimens from the genus Jabouilleia (Table 1; Fig. 2). The Myanmar-endemic $J$. naungmungensis is significantly distinctive in some morphometric features: the bill and hallux nail are significantly longer in the Hkakabo Razi population (naungmungensis) as compared with specimens from all other localities (ANOVA, bill length: $d f=1$, deviance $=7.161, \quad p<0.001 ; \quad$ wing: $\quad d f=1$, deviance $=0.256, \quad p<0.001 ;$ hallux nail: $d f=1$, deviance $=14.045, p<0.001)$. The innermost tail length 
and tail furcation also show significant differences (ANOVA, innermost tail length: $d f=1$, deviance $=4.198, \quad p=0.040, \quad$ tail furcation $d f=1$, deviance $=7.767, p=0.005$ ) , however, there is considerable overlap, at least for the innermost tail length (Fig. 2).

\section{Discussion}

Recognition of a new species, particularly one with close allopatric relatives, is a complex procedure; one that includes careful review by recognized experts from within the taxonomic group. Such a process was followed in The $A u k$ 's editorial review when the paper originally describing $J$. naungmungensis was accepted for publication (Rappole et al. 2005).

Collar and Robson (2007) chose to disregard recognition of the species in their account of the bird's closest known relative, J. danjoui, listing it as a subspecies of the Vietnamese bird. Their decision, as subsequently explained in a paper by Collar (2011), was based on a morphometric analysis and a plumage color analysis. The morphometric analysis, as described by Collar (2011), involved comparison of measurements from two J. naungmungensis with those from $11 \mathrm{~J}$. danjoui for four parameters, and did not include a statistical comparison. Though del Hoyo and Collar (2016) recognized J. naungmungensis as a full species based on a previously published sound recording (Rappole et al. 2008: Fig. 2 on p. 625) and differences in plumage coloration, they justified the previous subspecific rank in Collar and Robson (2007) with a "mistaken claim of morphometric differences" in the original description. However, with our new analysis, we provide firm evidence of significant differences between the two taxa in question in five out of ten biometric parameters. Thus, distinctive morphometrics support the recognition of the two as separate species.

However, Collar (2011) evidently leaned most heavily on plumage color analysis in his initial decision, although it should be noted that in his analysis, he applied a scoring method developed by Tobias et al. (2010), which was published after he had already published his original decision not to recognize $J$. naungmungensis as a separate species (Collar and Pilgrim 2007). In any event, for the plumage color comparison, Collar used three plumage color traits when comparing two J. naungmungensis with three $J$. danjoui. Based on this comparison of the individual scores for each trait and a total score of four for all traits combined, he concluded that the plumage color differences between $J$. naungmungensis and J. danjoui were "insufficient to achieve species status" (Collar 2011). Remarkably, del Hoyo and Collar (2016) came to a different conclusion by applying the same methodology to the same traits without analyzing any new data (i.e., they used the same data as before). Such inconsistencies in species diagnosis are one reason why the scoring method has been repeatedly criticized-it is prone to subjectivity and other potential pitfalls (Curry 2015; Martens 2014; Peterson and Moyle 2008).

Plumage color is, of course, an important characteristic of birds, given their dependence on vision. However, it is suspect when used as a sole defining character in taxonomic decisions regarding separation of species (Päckert 2015). There are at least four reasons why extreme caution should be taken in this regard: (1) taxa that are known to be members of the same species (based on known interbreeding) can differ significantly in color (e.g., among many possible examples in Rasmussen and Anderton 2005, the northwestern versus southeastern forms of the Redfaced Liocichla Liocichla phoenicea); (2) taxa that are known to be members of different species can show very little difference in color (e.g., again among many possible examples, several members of Empidonax, Phylloscopus, Thamnophilus, Elaenia, etc.); (3) color can vary significantly based on the methods used for specimen preparation, handling, and storage as well as with age (Armenta et al. 2008; Doucet and Hill 2009); and (4) color assessments performed without applying a quantitative method (such as spectrometry) are subjective, varying among observers (Peterson and Moyle 2008).

In our original description of J. naungmungensis as a unique species separate from its allopatric congener, $J$. danjoui, we were careful to present all of the information available in 2005 documenting the differences between the two species: acoustic, ecologic, and morphometric. For the purposes of this paper, we reperformed the morphometric work using a single investigator and included all 22 known specimens (14 danjoui, 4 naungmungensis, 4 parvirostris; all included in tests; Table 1; Fig. 2). In addition, we performed a new genetic analysis to augment the work done by S. Reddy (see citation in Renner and Rappole (2011), page 156), which has not been published to date (see "Results" section above and Fig. 2).

The results of our genetic work show a genetic distance value of $>7 \%$ (cyt $b$ ) between $J$. naungmungensis and $J$. danjoui. This distance equals or exceeds mean pairwise distances among other sister species in babblers, as we have shown. Thus, despite justified and reasonable criticism of the use of genetic distances as a threshold indicative of species status in birds (Rheindt and Austin 2005; Thomson et al. 2014), we consider J. naungmungensis to be genetically distinctive. Mean ages of Holarctic bird species (i.e., divergence time estimates for the split from their sister) have been estimated as corresponding to the Miocene/Pliocene boundary: 5.7-7.1 Ma for Himalayan 
species pairs (Price et al. 2014), about 5 Ma for Nearctic species pairs (Klicka and Zink 1997), and 3.9 Ma in a comprehensive comparison of avian genera (Johns and Avise 1998); sister species were not considered in the latter study, only randomly drawn congeners. Regardless of all the uncertainties associated with molecular dating, the deep split between $J$. naungmungensis and $J$. danjoui clearly exceeds intraspecific genetic variation in passerine birds as assessed to date. Moreover, the phylogenetic relationships between Jabouilleia and Rimator are not completely resolved. Paraphyly of Jabouilleia would be a strong argument against uniting $J$. danjoui and $J$. naungmungensis under the same species-level taxon. However, the sistergroup relationship between the Indochinese $J$. danjoui and $R$. albostriatus from Sumatra has received support only from mitochondrial genes and so further information from multi-locus data sets including $R$. pasquieri from northern Vietnam is needed. In any case, conspecific classification of $R$. m. albostriatus and $R$. m. malacoptilus (Dickinson and Christidis 2014; under the genus Napothera) is not supported by our phylogeny (for the species status of the latter and $R$. albostriatus, see del Hoyo and Collar 2016). Nevertheless, the deep split between J. naungmungensis and its eastern sister clade reflects a rather common phylogeographic pattern at the species level, i.e., an east-west disjunction between Central Himalayan endemics and their eastern Himalayan/Indochinese/Indo-Myanmar counterparts (Martens 2015; Päckert et al. 2012, 2015).

We recognize that there can be no completely definitive answer in the recognition of allopatric species. However, not to recognize two species as different as J. naungmungensis and $J$. danjoui undermines the entire process because of the very large number of congeners that are recognized as separate species based on far weaker data. In conclusion, based on an integrative concept of taxonomy, $J$. naungmungensis is a full species with significant and clear differentiation in the three independent and commonly used character sets of morphology (own data), genetics (own data), and bioacoustics (Rappole et al. 2008).

\footnotetext{
Acknowledgements Leaving aside all professional disagreements, we would like to thank Nigel Collar for the intense and very livelyand in the end fruitful-discussions on naungmungensis and other cases of bird nomenclature. We also would like to thank Frank Rheindt for the discussion of allopatric speciation and scoring systems. We thank the Ministry of Natural Resources and Conservation, Myanmar for permits and support. We thank the National Museum of Natural History, Smithsonian Institution (USNM), American Museum of Natural History (AMNH), Academy of Natural Sciences Philadelphia (ANSP), British Museum of Natural History (BMNH), Museum of Comparative Zoology (MCZ), and Museum Histoire Naturelle de Paris (MHNP) for allowing us to use their collections and for sending samples (USNM). The study was funded by UNESCO "Safeguarding Natural Heritage in Myanmar within the World Heritage Framework-Phase II" (50MYA4001; bilateral project, contract number 4500306550); further support was provided by
}

SYNTHESYS (FR6275, DE6206, GB108, GB4367, ES2501) and the National Geographic Society (GEFNE48-12). The funding organizations and Myanmar government agencies played no role in the study design, data collection and analysis, decision to publish, or preparation of the manuscript. Open access funding provided by University of Natural Resources and Life Sciences Vienna (BOKU).

Open Access This article is distributed under the terms of the Creative Commons Attribution 4.0 International License (http://crea tivecommons.org/licenses/by/4.0/), which permits unrestricted use, distribution, and reproduction in any medium, provided you give appropriate credit to the original author(s) and the source, provide a link to the Creative Commons license, and indicate if changes were made.

\section{References}

Alström P, Olsson U, Lei F (2013) A review of the recent advances in the systematics of the avian superfamily Sylvioidea. Chin Birds 4:99-131. doi:10.5122/cbirds.2013.0016

Armenta JK, Dunn PO, Whittingham LA (2008) Effects of specimen age on plumage color. Auk 125:803-808. doi:10.1525/auk.2008. 07006

Clements JF, Schulenberg TS, Iliff MJ, Roberson D, Fredericks TA, Sullivan BL, Wood CL (2015) The eBird/Clements checklist of birds of the world: v2015. Cornell University Press, Ithaca

Collar NJ (2011) Taxonomic notes on some Asian babblers (Timaliidae). Forktail 27:100-102

Collar NJ, Pilgrim JD (2007) Species-level changes proposed for Asian birds, 2005-2006. BirdingASIA 8:14-30

Collar NJ, Robson C (2007) Family Timaliidae (Babblers). In: del Hoyo J, Elliot A, Sargatal J (eds) Handbook of the birds of the world, vol 12, 1st edn. Lynx, Barcelona, pp 70-291

Curry B (2015) What is a species? A critique of the Tobias scoring system used in the Illustrated Checklist of the Birds of the World. OFO News 33:9-11

del Hoyo J, Collar NJ (2016) Illustrated checklist of the birds of the world, vol 2-Passerines. Lynx Editions, Barcelona

Delacour J (1927) Descriptions of two new genera and forty new species and subspecies collected during the 3rd expedition to French Indo-China in 1926-27. Bull $\mathrm{Br}$ Ornithol Club 47:151-169

Dickinson EC, Christidis L (2014) The Howard and Moore complete checklist of birds of the world, vol 2, 4th edn. Aves, Eastborne

Doucet SM, Hill GE (2009) Do museum specimens accurately represent wild birds? A case study of carotenoid, melanin, and structural colours in long-tailed manakins Chiroxiphia linearis. J Avian Biol 40:146-156. doi:10.1111/j.1600-048X.2009.03763. $\mathrm{x}$

Drummond AJ, Rambaut A (2007) BEAST: Bayesian evolutionary analysis by sampling trees. BMC Evol Biol 7:214. doi:10.1186/ 1471-2148-7-214

Eames JC, Mahood S (2011) White-throated Wren Babbler Rimator pasquieri: Vietnam's rarest endemic passerine? BirdingASIA 15:58-62

Eck S et al (2011) Measuring birds (Vögel vermessen). Christ Media, Minden

Johns GC, Avise JC (1998) A comparative summary of genetic distances in the vertebrates from the mitochondrial cytochrome $b$ gene. Mol Biol Evol 15:1481-1490

Klicka J, Zink RM (1997) The importance of recent ice ages in speciation: a failed paradigm. Science 277:1666-1669. doi:10. $1126 /$ science.277.5332.1666 
Martens J (2014) Kritik an der Scoring-Methode nach Tobias-Art oder Nicht-Art. Falke 61:18-21

Martens J (2015) Fauna-Himalayan patterns of diversity. In: Miehe $G$ (ed) Nepal: an introduction to the natural history, ecology and human environment of the Himalayas. Royal Botanic Garden, Edinburgh, pp 211-249

Moyle RG, Andersen MJ, Oliveros CH, Steinheimer FD, Reddy S (2012) Phylogeny and biogeography of the core babblers (Aves: Timaliidae). Syst Biol 61:631-651. doi:10.1093/sysbio/ sys027

Nyári ÁS, Reddy S (2013) Comparative phyloclimatic analysis and evolution of ecological niches in the scimitar babblers (Aves: Timaliidae: Pomatorhinus). PLoS One 8:e55629. doi:10.1371/ journal.pone.0055629

Oliveros CH, Reddy S, Moyle RG (2012) The phylogenetic position of some Philippine "babblers" spans the muscicapoid and sylvioid bird radiations. Mol Phylogenet Evol 65:799-804. doi:10.1016/j.ympev.2012.07.029

Päckert M (2015) Vom Sinn und Unsinn einer reduktionistischen. Biologie Vogelwarte 53:51-58

Päckert M, Martens J, Sun YH (2010) Phylogeny of long-tailed tits and allies inferred from mitochondrial and nuclear markers (Aves: Passeriformes, Aegithalidae). Mol Phylogenet Evol 55:952-967. doi:10.1016/j.ympev.2010.01.024

Päckert M et al (2012) Horizontal and elevational phylogeographic patterns of Himalayan and Southeast Asian forest passerines (Aves: Passeriformes). J Biogeogr 39:556-573. doi:10.1111/j. 1365-2699.2011.02606.x

Päckert M, Martens J, Sun YH, Tietze DT (2015) Evolutionary history of passerine birds (Aves: Passeriformes) from the Qinghai-Tibetan plateau: from a pre-Quarternary perspective to an integrative biodiversity assessment. J Ornithol 156:S355S365. doi:10.1007/s10336-015-1185-6

Peterson AT, Moyle RG (2008) An appraisal of recent taxonomic reappraisals based on character scoring systems. Forktail $24: 110-112$

Price TD et al (2014) Niche filling slows the diversification of Himalayan songbirds. Nature 509:222-225. doi:10.1038/ nature 13272

Rappole JH, Renner SC, Shwe NM, Sweet PR (2005) A new species of Scimitar-Babbler (Timaliidae: Jabouilleia) from the subHimalayan region of Myanmar. Auk 122:1064-1069. doi:10.1642/0004-8038(2005)122[1064:Ansost]2.0.Co;2

Rappole JH, Rasmussen PC, Aung T, Milensky CM, Renner SC (2008) Observations on a new species: the Naung Mung Scimitar-Babbler Jabouilleia naungmungensis. Ibis 150:623-627. doi:10.1111/j.1474-919X.2008.00815.x
Rasmussen PC, Anderton JC (2005) Birds of South Asia: the Ripley guide, 1st edn. Lynx Edicions/Smithsonian, Barcelona/Washington, DC,

Reddy S (2008) Systematics and biogeography of the shrike-babblers (Pteruthius): species limits, molecular phylogenetics, and diversification patterns across southern Asia. Mol Phylogenet Evol 47:54-72

Reddy S, Moyle RG (2011) Systematics of the scimitar babblers (Pomatorhinus: Timaliidae): phylogeny, biogeography, and species-limits of four species complexes. Biol J Lin Soc 102:846-869

Renner SC, Rappole JH (2011) Bird diversity, biogeographic patterns, and endemism of the eastern Himalayas and southeastern subHimalayan mountains. In: Morrison ML (ed) Ornithological monographs, vol. 70. Avifauna of the eastern Himalayas and southeastern sub-Himalayan mountains - center of endemism or many species in marginal habitats? American Ornithologists' Union, Washington, DC, pp 153-166

Renner SC, Rappole JH, Milensky CM, Milensky CM, Aung M, Shwe NM (2015) Avifauna of the southeastern Himalayan mountains and neighboring Myanmar hill country. Bonn Zool Bull Suppl 62:1-75

Rheindt FE, Austin JJ (2005) Major analytical and conceptual shortcomings in a recent taxonomic revision of the Procellariiformes-a reply to Penhallurick and Wink (2004). Emu 105:181-186. doi:10.1071/Mu04039

Robinson HC, Kloss CB (1919) XXII. On birds from South Annam and Cochin China. Part I. Ibis 61:392-453. doi:10.1111/j.1474919X.1919.tb02892.x

Silvestro D, Michalak I (2012) raxmlGUI: a graphical front-end for RAxML. Org Divers Evol 12:335-337

Stamatakis A (2006) RAxML-VI-HPC: maximum likelihood-based phylogenetic analyses with thousands of taxa and mixed models. Bioinformatics 22:2688-2690

Svensson L (1992) Identification guide to European passerines. British Trust for Ornithology, Stockholm

Tamura K, Stecher G, Peterson D, Filipski A, Kumar S (2013) MEGA6: molecular evolutionary genetics analysis version 6.0. Mol Biol Evol 30:2725-2729. doi:10.1093/molbev/mst197

Thomson CE, Gilbert JD, Brooke LM (2014) Cytochrome b divergence between avian sister species is linked to generation length and body mass. PLoS One 9:e85006. doi:10.1371/journal. pone.0085006

Tobias JA, Seddon N, Spottiswoode CN, Pilgrim JD, Fishpool LDC, Collar NJ (2010) Quantitative criteria for species delimitation. Ibis 152:724-746

Weir JT, Schluter D (2008) Calibrating the avian molecular clock. Mol Ecol 17:2321-2328. doi:10.1111/j.1365-294X.2008.03742.x 